\title{
THE IMPACT OF SERVICE QUALITY ON CUSTOMER LOYALTY WITH CUSTOMER SATISFACTION AS A MEDIATION VARIABLE IN HORISON ULTIMA HOTEL PALEMBANG
}

\author{
Revie Marisky*, Zakaria Wahab, Marlina Widiyanti, and Isnurhadi \\ Magister Management Faculty Economic Sriwijaya University Indonesia. \\ http://doi.org/10.35409/IJBMER.2019.2410
}

\begin{abstract}
This study aims (1) to determine the effect of service quality on consumer satisfaction, (2) to know the effect of customer satisfaction on consumer loyalty, (3) to know the effect of service quality on consumer loyalty, (4) to determine the effect of mediating customer satisfaction on influence quality of service to consumer loyalty at the Palembang Horison Ultima Hotel. The population in this study were consumers of the Horison Ultima Palembang Hotel with a purposive sampling method sampling with 200 respondents. data collection techniques using a questionnaire. data analysis using path analysis. from this study it can be concluded that (1) service quality affects consumer satisfaction, (2) service quality affects consumer loyalty, (3) consumer satisfaction influences consumer loyalty, and (4) customer satisfaction can mediate the effect of service quality on consumer loyalty at the hotel horsion ultima palembang.
\end{abstract}

Keyword: service quality, customer satisfaction, customer loyalty

\section{INTRODUCTION}

Rapid technological developments, which affect economic growth and business competition in all parts of the world. This also affects Indonesia, as the largest archipelagic country in the world. Economic development in Indonesia is also greatly increasing, especially in the service sector industry. One of the service sectors that is a mainstay of Indonesia is the tourism industry which is one of the industries that promises rapid economic growth.

Hotels are companies or business entities that provide lodging services, food and beverage providers, and other service facilities where all services are intended for the general public, whether they stay overnight at the hotel or those who only use certain facilities owned by the hotel. described as one of the service companies that prioritizes service to customers.

Increasing competition between hotels causes each hotel to try to provide the best quality and service to its customers. A hospitality service company can be said to be successful if it is able to provide services or services that can meet or exceed customer expectations (Kotler (2013: p.83). Service quality is an important matter to be considered by a hospitality business, because it is one service business that is not easy to manage in providing good facilities and services for its guests.

Hotels have a very crucial role in supporting tourism activities in a region. Fast-growing 
Vol. 2, No. 04; 2019

ISSN: 2581-4664

tourism supported by increasing numbers of tourists will encourage the construction of hotels. Hotels that currently exist, offer a variety of facilities that can be enjoyed by their guests, these facilities include swimming pools, fitness centers, spas, room services and so on. These facilities are given to hotel guests with the aim of providing services and meeting guests' needs.

Table 1. Room Occupancy Rate (TPK), Number of Foreign Guests (Wisman) and Nusantara Guests (Wisnus) who Stay in Starred Hotels According to Hotel Classifications in South Sumatra July 2018- August 2018 (Number of Guests Staying)

\begin{tabular}{|c|c|c|c|c|c|c|c|c|}
\hline \multirow[t]{2}{*}{$\begin{array}{l}\text { Qualification } \\
\text { Star }\end{array}$} & \multicolumn{2}{|c|}{ Foreign } & \multicolumn{2}{|c|}{ Indonesia } & \multicolumn{2}{|l|}{ Total } & \multicolumn{2}{|c|}{$\begin{array}{l}\text { Room } \\
\text { Occupancy } \\
\text { Rate (ROR) \% }\end{array}$} \\
\hline & $\begin{array}{l}\text { July } \\
2018\end{array}$ & $\begin{array}{l}\text { August } \\
2018\end{array}$ & $\begin{array}{l}\text { July } \\
2018\end{array}$ & $\begin{array}{l}\text { August } \\
2018\end{array}$ & $\begin{array}{l}\text { July } \\
2018\end{array}$ & $\begin{array}{l}\text { August } \\
2018\end{array}$ & $\begin{array}{l}\text { July } \\
2018\end{array}$ & $\begin{array}{l}\text { August } \\
2018\end{array}$ \\
\hline Star 1 & 11 & 19 & 6.843 & 7.242 & 6.854 & 7.261 & 54,29 & 51,51 \\
\hline Star 2 & 311 & 603 & 35.284 & 32.210 & 35.595 & 32.813 & 50,65 & 63,77 \\
\hline Star 3 & 160 & 418 & 38.255 & 27.348 & 38.415 & 27.766 & 62,85 & 52,19 \\
\hline Star 4 & 783 & 2.149 & 29.483 & 26.880 & 30.266 & 29.029 & 60,35 & 66,15 \\
\hline Star 5 & 418 & 228 & 14.136 & 11.430 & 14.554 & 11.658 & 68,82 & 95,11 \\
\hline
\end{tabular}

The star-rated Room Occupancy Rate (TPK) in South Sumatra in August 2018 reached an average of $62.35 \%$, up 3.82 points compared to the hotel TPK in July 2018 of $58.53 \%$. Meanwhile, if observed according to hotel classification, it turns out that in August 2018 ROR for five-star hotels reached $95.11 \%$ and was the highest TPK compared to other star-rated hotels. While the lowest ROR for hotels is one-star hotels, which reached $51.51 \%$.

Horison Ultima Hotel Palembang has 172 rooms consisting of 10 floors. As a business hotel, Horison Ultima Hotel Palembang provides different facilities, namely the number of Business Centers \& Banquet Amenities that is more than other hotels in Palembang. The total meeting rooms that we have are 22 meeting rooms, with 1 ballroom with a capacity of 2500 pax. To relax, guests can visit the restaurant and lounge. We also provide a fitness center such as a gym center, swimming pool, sauna and spa.

Tabel 2. Guest response to the Horison Ultima Palembang Hotel in February 2019

\begin{tabular}{|c|c|c|c|c|c|c|}
\hline \multirow[b]{2}{*}{ No. } & \multirow[b]{2}{*}{ Name } & \multirow{2}{*}{$\begin{array}{l}\text { Number } \\
\text { Room }\end{array}$} & \multicolumn{2}{|c|}{ Period of Stay } & \multirow[b]{2}{*}{ Positive comment } & \multirow[b]{2}{*}{ Negative Comment } \\
\hline & & & $\mathrm{C} / \mathrm{I}$ & $\mathrm{C} / \mathrm{O}$ & & \\
\hline 1 & Santi & 528 & $2 / 2 / 19$ & $3 / 2 / 19$ & $\begin{array}{l}\text { It's fun, it can be a } \\
\text { reference to friends } \\
\text { when going to } \\
\text { Palembang }\end{array}$ & $\begin{array}{l}\text { But please see the } \\
\text { cleanliness more }\end{array}$ \\
\hline 2 & Andry K & 807 & $2 / 2 / 19$ & $3 / 2 / 19$ & $\begin{array}{l}\text { Spacious room, good } \\
\text { and best food }\end{array}$ & Unfriendly service \\
\hline 3 & Ridho $S$ & 524 & $3 / 2 / 19$ & $4 / 2 / 19$ & $\begin{array}{l}\text { Good Job. I really like } \\
\text { and comfortable }\end{array}$ & - \\
\hline 4 & William & 903 & $4 / 2 / 19$ & $5 / 2 / 19$ & 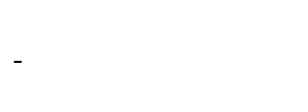 & $\begin{array}{l}\text { Parking for hotel } \\
\text { guests and guest } \\
\text { guests please separate }\end{array}$ \\
\hline 5 & Surtam & 1020 & $6 / 2 / 19$ & $7 / 2 / 19$ & $\begin{array}{l}\text { Strategic location, } \\
\text { ciukup deposit paid }\end{array}$ & Only one room key \\
\hline
\end{tabular}




\section{International Journal of Business Management and Economic Review}

Vol. 2, No. 04; 2019

ISSN: 2581-4664

\begin{tabular}{|c|c|c|c|c|c|c|}
\hline & & & & & $\begin{array}{l}200 \text { thousand, big and } \\
\text { clean akmar, strong } \\
\text { wifi, quite varied } \\
\text { breakfast menu }\end{array}$ & \\
\hline 6 & $\begin{array}{l}\text { Ahmad } \\
\text { Romaddon }\end{array}$ & 802 & $9 / 2 / 19$ & $10 / 2 / 19$ & Overall good & $\begin{array}{l}\text { Room service little bit } \\
\text { slow, little bit move } \\
\text { proactive }\end{array}$ \\
\hline 7 & Tri Anggraini & 627 & $11 / 2 / 19$ & $13 / 2 / 19$ & $\begin{array}{l}\text { Food has many } \\
\text { variations and tastes }\end{array}$ & - \\
\hline 8 & Iin Parlina & 806 & $14 / 2 / 19$ & $16 / 2 / 19$ & $\begin{array}{l}\text { Strategic location, } \\
\text { quite varied food, } \\
\text { friendly staff }\end{array}$ & - \\
\hline 9 & Sukamto & 906 & $17 / 2 / 19$ & $18 / 2 / 19$ & $\begin{array}{l}\text { The rooms are clean, } \\
\text { breakfast is relatively } \\
\text { ordinary. Friendly } \\
\text { service especially Nisa } \\
\text { and Anis as their top } \\
\text { friendly FO. }\end{array}$ & - \\
\hline 10 & Gea Andini & 904 & $23 / 2 / 19$ & $25 / 2 / 19$ & 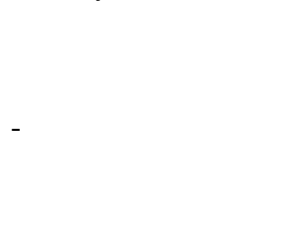 & $\begin{array}{l}\text { Fun, only less close to } \\
\text { the mall and have to } \\
\text { turn around. Muslim } \\
\text { prayer equipment such } \\
\text { as prayer mats, } \\
\text { sarongs or mukena are } \\
\text { not held }\end{array}$ \\
\hline
\end{tabular}

Based on Table 2, it can be seen that some consumers were satisfied with the facilities and services provided by the Palembang Horison Ultima Hotel, but there were also several consumers who commented negatively about some of the lack of facilities and services provided by the Palembang Horison Ultima Hotel. Therefore, Palembang Horison Ultima Hotel must pay attention and improve what the hotel consumers think is for the continuity and progress of the Palembang Ultima Horison Hotel to be better for the future.

Consumer satisfaction is an important thing and must be considered every response they give, because they are the ones who are the preferred marketing target in the continuity and progress of the Palembang Horison Ultima Hotel for the better.

Based on the background of the problem described above, the research problem formulation is Service Quality carried out on customers of Palembang Horison Ultima Hotel and the results or conclusions of several different studies on factors that influence performance (research gap). This is indicated by the findings that have not been uniform regarding the differences in the effect of Service Quality on Customer Satisfaction and Customer Loyalty.

Service Quality Factors have an effect on Customer Loyalty through Customer Satisfaction as a mediating variable shown in Anthony's research (2019); Adhitya (2018) and Afifa (2018) which shows that Service Quality influences Customer Loyalty through Customer Satisfaction.

The Service Quality factor is also very important for creating customer satisfaction. Anthony (2019) and Brigitte (2019) in their research show that there is a positive and significant influence between Service Quality on Customer Satisfaction.

Based on the background above, encouraging researchers to conduct research with the title Effect of Service Quality on Customer Loyalty with Customer Satisfaction as a Mediation Variable at Palembang Horison Ulitima Hotel. 


\section{International Journal of Business Management and Economic Review}

Vol. 2, No. 04; 2019

ISSN: 2581-4664

The objectives to be achieved in this study are: To find out whether service quality and customer satisfaction affect the customer loyalty of the Palembang Horison Ultima Hotel and to find out whether customer satisfaction mediates service quality on customer loyalty in the Horison Ultima Palembang Hotel.

\section{LITERATURE REVIEW}

\section{a. Service Quality}

Service Quality is a measure of how well the level of service provided is able to match customer expectations (Tjiptono, 2012: 157). Based on this understanding, it can be concluded that service quality is an economic activity whose output is not a consumer product, together with production time and providing added value (such as enjoyment, entertainment) that is intangible and if services received by the customer are as expected, quality service is perceived as good (ideal) and vice versa if the service received is lower than expected by consumers, then service quality and perceived bad (less ideal) so that the needs and desires of consumers feel beben fulfilled.

\section{b. Customer Loyalty}

According to Griffin (2013: 15), loyalty is a form of behavior of decision-making units to make continuous purchases of goods for the services of a selected company.

\section{c. Effect of Service Quality on Customer Satisfaction}

Consumer satisfaction is the level of one's feelings after comparing (performance or results) that is felt compared to expectations (Kotler in Sunyoto's book (2013: 35)). Service quality is a benchmark in determining customer satisfaction or not a service user, because through service quality will be able to assess performance and feel satisfied or not consumers with services provided by service providers. Good service quality, the decisions of many consumers will have a positive impact because the quality of service can provide more value to customer satisfaction.

\section{d. Effect of Service Quality on Customer Loyalty}

Customer loyalty is a manifestation of the behavior of decision-making units to make continuous purchases of goods for the services of a selected company (Griffin, 2013: 15). Customer loyalty is one factor that can benefit marketers. This loyalty is a post-purchase or product usage behavior. The form of loyalty that can be seen empirically is the re-purchase and recommendation. Customer Loyalty to a service does not necessarily arise. Then it takes effort to build and maintain that loyalty. Some things that are of concern in building and maintaining customer loyalty are the quality of services provided to customers.

\section{e. Effect of Service Quality on Customer Loyalty at Mediation by Customer Satisfaction}

Customers who decide to be loyal to a product or service are often caused because they feel the services provided by the company are not only in accordance with their needs, but also satisfying and pleasant. Types of marketing services that are often called excellent services are always expected by customers.

\section{RESEARCH METHODS}

a. Types and Data Sources

The data sources used in this study are primary data. Primary data is data obtained directly from observation (observation) and the results of questionnaires given to respondents (Sekaran, 2013). Sources of data used in this study are primary data, namely data collected by researchers 


\section{International Journal of Business Management and Economic Review}

Vol. 2, No. 04; 2019

ISSN: 2581-4664

when conducting research.

b. Population and Samples

The data sources used in this study are primary data. Primary data is data obtained directly from observation (observation) and the results of questionnaires given to respondents (Sekaran, 2013). Sources of data used in this study are primary data, namely data collected by researchers when conducting research.

c. Path Analysis Method

Path analysis is a technique for analyzing causal relationships that occur in multiple regression if the independent variable influences variables depending not only directly but also indirectly. The purpose of path analysis according to Pardede (2014: 17) is to determine the magnitude of the direct effect of a number of variables based on beta regression coefficient (beta / $\beta$ coefficient). The coefficient in the system path analysis equation is the standardized coefficients. Path analysis techniques are used in testing the magnitude of the contribution (contribution) indicated by the path coefficient on each path diagram of the causal relationship between variables X to Y and their impact on Z (Gudono, 2011: 218). According to Ghozali (2013: 98), saying that in social research is not merely expressing the relationship of variables as a statistical translation of the relationship between natural variables, but focuses on efforts to express causal relationships between variables. In the path diagram two types of arrows are used, namely:

a. A one-way arrow that expresses the direct effect of an exogenous variable (cause variable $(\mathrm{X})$ ) on an endogenous variable (variable effect $(\mathrm{Y})$ ) for example: $\mathrm{X} 1 \mathrm{Y}$

b. Two-way arsow which states the correlation relationship between exogenous variables, for example X1

\section{RESULTS AND DISCUSSION}

a. Validity Test Results

Table 3. Validity Test Results

\begin{tabular}{|lllll|}
\hline Variable & $\begin{array}{l}\text { Item } \\
\text { Pertanyaan }\end{array}$ & r count & r table & Conclusion \\
\hline Service & X1.1 & 0,724 & 0,1388 & Valid \\
Quality (X) & X1.2 & 0,681 & 0,1388 & Valid \\
& X1.3 & 0,732 & 0,1388 & Valid \\
& X1.4 & 0,628 & 0,1388 & Valid \\
& X1.5 & 0,627 & 0,1388 & Valid \\
& & & & \\
\hline Customer & Z.1 & 0,636 & 0,1388 & Valid \\
Satisfaction & Z.2 & 0,409 & 0,1388 & Valid \\
(Z) & Z.3 & 0,572 & 0,1388 & Valid \\
& Z.4 & 0,681 & 0,1388 & Valid \\
& Z.5 & 0,599 & 0,1388 & Valid \\
\hline Customer & Y.1 & 0,221 & 0,1388 & Valid \\
Loyalty (Y) & Y.2 & 0,132 & 0,1388 & Unvalid \\
& Y.3 & 0,279 & 0,1388 & Valid \\
& Y.4 & 0,071 & 0,1388 & Unvalid \\
\hline
\end{tabular}

Source: Questionnaire data processed using SPSS 


\section{International Journal of Business Management and Economic Review}

Vol. 2, No. 04; 2019

ISSN: 2581-4664

The results of the calculation of the validity test indicate that the question indicators of the variable Sevice Quality (X), Customer Satisfaction (Z), and Customer Loyalty (Y) submitted by the researcher against the respondent are valid because the rhitung value> rtable.

\section{b. Reliability Test Results}

Table 4. Reliability Test Results

\begin{tabular}{|llll|}
\hline Variable & Cronbach's Alpha & $\begin{array}{l}\text { Value } \\
\text { Reliable }\end{array}$ & Conclusion \\
\hline Service quality (X) & 0,686 & 0,600 & Reliable \\
\hline $\begin{array}{l}\text { Customer } \\
\text { satisfaction (Z) }\end{array}$ & 0,511 & 0,600 & Unreliable \\
\hline $\begin{array}{l}\text { Customer loyalty } \\
(Y)\end{array}$ & 0,567 & 0,600 & Unreliable \\
\hline
\end{tabular}

Sumber: Data kuesioner yang diolah menggunakan SPSS

From Table 4 The reliability test results above show that the cronbachs alpha value for all variable variables is above 0.6 or cronbachs alpha> 0.6 so that it is feasible to be tested to the next test.

\section{RESULTS OF DATA ANALYSIS}

\section{a. Path Analysis}

Analysis of Sub-Structural Equations I

Analysis of sub-structural equations I was conducted to determine the strength of the influence of the independent variable on the intervening variable. In this analysis using the substructural equation I, namely:

\section{Coefficient of Determination}

The coefficient of determination (R2) equation I aims to determine how much the variable ability is perceived value $(X)$ and service quality $(Z)$ as a whole in explaining the variable quality of service. The results of the coefficient of determination analysis can be seen as follows:

\begin{tabular}{|c|c|c|c|c|c|}
\hline \multicolumn{6}{|c|}{ Model Summary ${ }^{b}$} \\
\hline Model & $\mathrm{R}$ & R Square & $\begin{array}{l}\text { Adjusted } \\
\text { Square }\end{array}$ & $\mathrm{R}$ & $\begin{array}{l}\text { Std. Error of the } \\
\text { Estimate }\end{array}$ \\
\hline 1 & $.238^{\mathrm{a}}$ & .056 & .052 & & 4.209 \\
\hline \multicolumn{6}{|c|}{$\begin{array}{l}\text { a. Predictors: (Constant), X } \\
\text { b. Dependent Variable: Z } \\
\text { Source: Questionnaire data processed using SPSS }\end{array}$} \\
\hline
\end{tabular}

The Summary Model can be concluded that the R square R2 value obtained for the effect of service quality on customer satisfaction is 0.056 so that it is obtained from:

$$
\begin{aligned}
& \rho \varepsilon_{1}=\sqrt{1-R^{2}} \\
& \rho \varepsilon_{1}=\sqrt{1-0,056}=0,971
\end{aligned}
$$

The coefficients that cannot be explained in the path equation model are $1-0.056=0.944$ Schematically, the path equation model for $\mathrm{H} 1$ is presented in the following figure 


\section{International Journal of Business Management and Economic Review}

Vol. 2, No. 04; 2019

ISSN: $2581-4664$

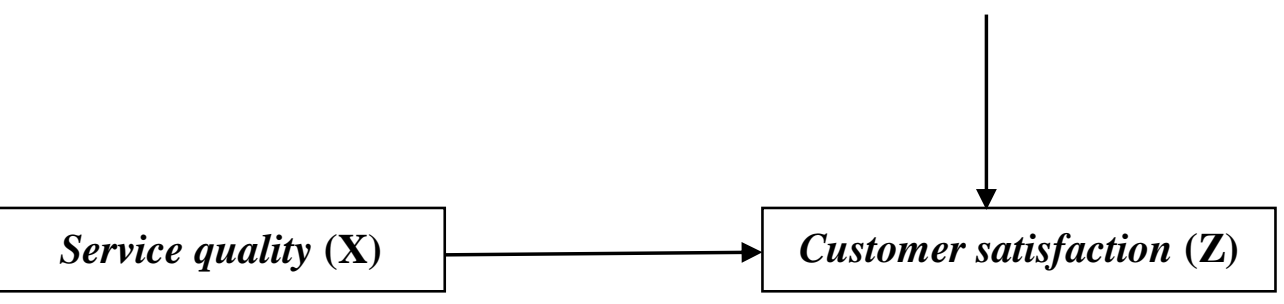

\section{Testing Variable Service Quality to Customer Satisfaction}

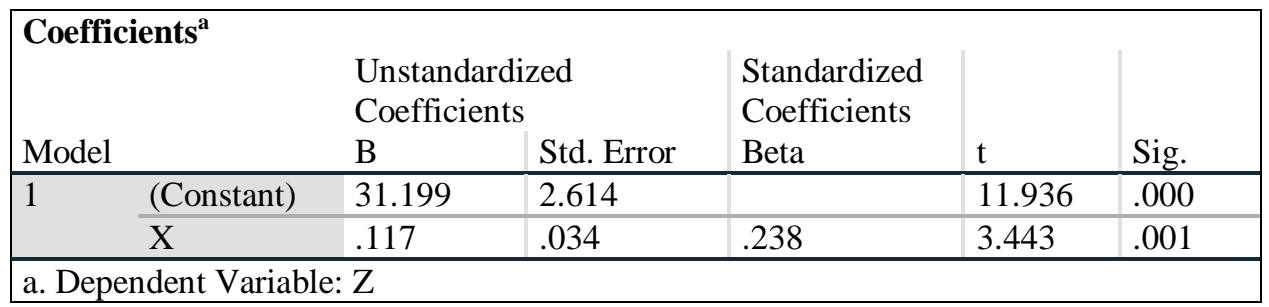

Source: Questionnaire data processed using SPSS

Based on the coefficients table, it is known that the service quality (X) variable has a significance value of 0.001 when compared with $\alpha=0.05$, then the sig value $<\alpha$ value $(0.001$ $<0.05$ ). Thus $\mathrm{H} 1$ is accepted. This shows that service quality has an effect on customer satisfaction. The amount of beta (path coefficient) variable service quality (X) to customer satisfaction $(Z)$ is 0.238 ( $\rho y x I)$.

$$
\mathrm{Z}=\mathbf{0 , 2 3 8 X}+\mathbf{0 , 9 7 1} \varepsilon_{1}
$$

This equation describes the causal effect of service quality $(\mathrm{X})$ variable on customer satisfaction (Z), based on significance testing, the service quality (X) variable has an effect on customer satisfaction $(Z)$ with a beta value of 0.238 which shows the influence on the customer satisfaction $(Z)$, thus, the level of customer satisfaction is influenced by service quality.

\section{b. Analysis of sub-structural equations II}

Analysis of sub-structural equation II was conducted to determine the effect of independent variables on dependent variables. In the regression analysis using sub-structural equation III, namely:

$$
\mathbf{Y}=\rho_{\mathrm{Y}} \mathbf{X X}+\rho_{\mathrm{YZ}} \mathrm{Y}+\varepsilon_{2}
$$

\section{The coefficient of determination ( $R 2)$}

The coefficient of determination (R2) equation II aims to determine how much the variable service quality $(\mathrm{X})$ customer satisfaction $(\mathrm{Z})$ and explain the customer loyalty variable $(\mathrm{Y})$. The results of the coefficient of determination analysis can be seen as follows:

Calculation results of the determination coefficients $\mathrm{X}$ and $\mathrm{Z}$ on $\mathrm{Y}$

\begin{tabular}{|l|l|l|l|}
\hline \multicolumn{2}{|l|}{ Model Summary } \\
Model $\quad \mathrm{R}$ & R Square & $\begin{array}{l}\text { Adjusted } \\
\text { Square }\end{array}$ & $\begin{array}{l}\text { R } \\
\text { Std. Error of the } \\
\text { Estimate }\end{array}$ \\
\hline 1 .420 & .177 & .168 & 4.177 \\
\hline $\begin{array}{l}\text { a. Predictors: (Constant), Z, X } \\
\text { b. Dependent Variable: } \mathrm{Y}\end{array}$ \\
\hline
\end{tabular}




\section{International Journal of Business Management and Economic Review}

Vol. 2, No. 04; 2019

ISSN: $2581-4664$

Source: Questionnaire data processed using SPSS

$\mathrm{R}^{2}$ is obtained for the effect of participant's decision on service quality of 0.177 so that it is obtained from:

$$
\begin{aligned}
& \varepsilon_{2}=\sqrt{1-R^{2}} \\
& \rho \varepsilon_{2}=\sqrt{1-0,177}=0,907
\end{aligned}
$$

the coefficients that cannot be explained in the path equation model are $1-0.177=0.823$. Schematically, the path II equation model is presented in the following figure:

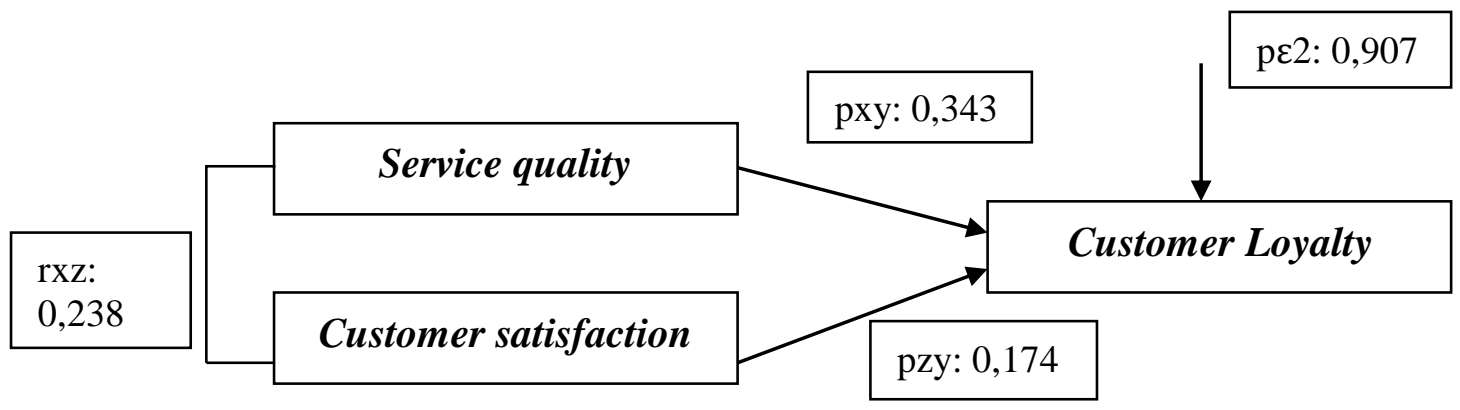

\section{Test for Individual Parameter Significance}

The magnitude of the effect of the service quality (X) variable on customer loyalty $(\mathrm{Y})$ is shown by the coefficients table. The test results are presented in the following table:

\begin{tabular}{|c|c|c|c|c|c|c|}
\hline \multicolumn{7}{|c|}{ Coefficients $^{\mathrm{a}}$} \\
\hline \multirow{2}{*}{\multicolumn{2}{|c|}{ Model }} & \multicolumn{2}{|c|}{$\begin{array}{l}\text { Unstandardized } \\
\text { Coefficients }\end{array}$} & \multirow{2}{*}{$\begin{array}{l}\text { Standardized } \\
\text { Coefficients } \\
\text { Beta }\end{array}$} & \multirow[b]{2}{*}{$\mathrm{t}$} & \multirow[b]{2}{*}{ Sig. } \\
\hline & & B & Std. Error & & & \\
\hline 1 & (Constant) & 17.461 & 3.401 & & 5.134 & .000 \\
\hline & $\mathrm{X}$ & .180 & .035 & .343 & 5.155 & .000 \\
\hline & $\mathrm{Z}$ & .185 & .071 & .174 & 2.621 & .009 \\
\hline
\end{tabular}

Testing Service Quality (X) Variables with Customer Satisfaction (Z) on Customer Loyalty (Y)

Source: Questionnaire data processed using SPSS

\section{Variable testing of service quality $(X)$ on customer loyalty $(Y)$}

Based on the coefficients table, it is known that the customer loyalty variable ( $\mathrm{Y}$ ) has a sig value. As much as 0,000 when compared with $\alpha=0,05$, then the value of sig $<$ value $\alpha(0,000$ $<0,05)$. Thus $\mathrm{H} 2$ is accepted. This shows that service quality affects customer loyalty. The amount of beta (path coefficient) of customer satisfaction $(\mathrm{Z})$ variable on customer loyalty $(\mathrm{Y})$ is 0.343 .

\section{Results of Sub-Structural Equations II}

$$
\begin{aligned}
& Y=\rho_{y x} X+\rho_{y z} Z+\varepsilon_{2} \\
& Y=0,343 X+0,174 Z+0,907 \varepsilon_{2}
\end{aligned}
$$




\section{International Journal of Business Management and Economic Review}

Vol. 2, No. 04; 2019

ISSN: 2581-4664

This equation describes the causal effect of service quality $(\mathrm{X})$ variables on customer loyalty variables $(\mathrm{Y})$. Based on the significance test, the service quality $(\mathrm{X})$ variable influences the customer loyalty (Y) variable because service quality (X) has a sig value < probability value of 0.05 , so $\mathrm{H} 1$ is accepted. The value of 0.343 shows the influence of the service quality (X) variable on the customer loyalty variable (Y). Thus the level of customer loyalty is influenced by service quality $(\mathrm{X})$ of $34.3 \%$.

VI. Direct influence and indirect influence The direct effect of service quality (X) on participants' decisions (Y)

Based on the results of sub-structural equations I and II that have been carried out it can be concluded that from the service quality $(\mathrm{X})$ variable direct effect on customer loyalty $(\mathrm{Y})$ has a greater yield than the indirect effect $(0.343>-0.028)$, while for total influence of each service quality $(\mathrm{X})$ variable, participant's decision $(\mathrm{Y})$, and service quality $(\mathrm{Z})$ is for variable $\mathrm{X}$ against $\mathrm{Z}$ equal to 0.238 , variable $\mathrm{Z}$ to $\mathrm{Y}$ is 0.174 , variable $\mathrm{X}$ to $\mathrm{Y}$ is 0.343 . So that the indirect effect of service quality variable on customer satisfaction is $0.238 \times 0.174=0.041$ and the total effect is $0.343+0.041=0.384$.

\begin{tabular}{|llll|}
\hline Influence & Direct & indirect (via Y) & Total \\
\hline $\mathrm{X} \rightarrow \mathrm{Z}$ & 0,238 & & 0,238 \\
\hline $\mathrm{Z} \rightarrow \mathrm{Y}$ & 0,174 & & 0,174 \\
\hline $\mathrm{X} \rightarrow \mathrm{Y}$ & 0,343 & 0,041 & 0,384 \\
\hline
\end{tabular}

Source: Questionnaire data processed using SPSS

Based on the table above it can be concluded that the indirect effect of service quality on customer loyalty through the customer satisfaction variable is 0.041 and the total effect is 0.384 . Therefore, schematically the path equation for mediating service quality variables on the effect of service quality on customer loyalty is:

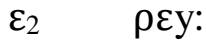

0,907

$\rho x y: 0,343$

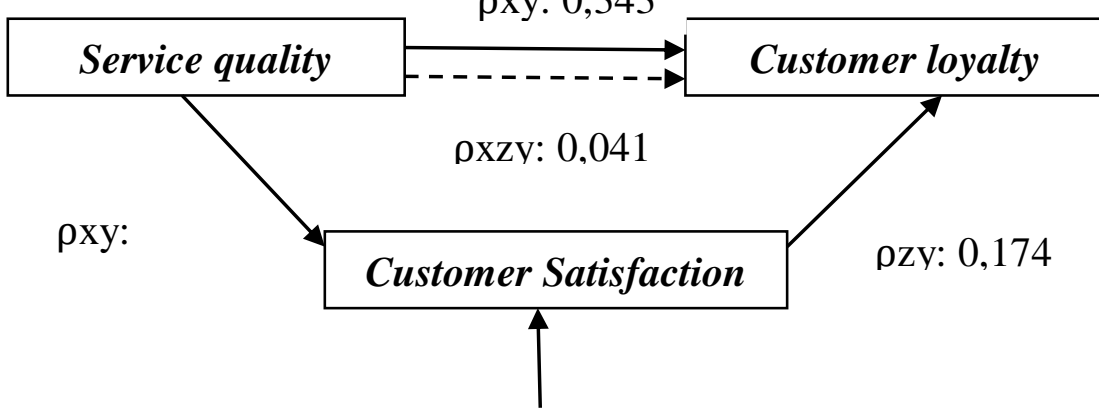

Schematic Image of Path Equations for Mediation of Customer Satisfaction Variables Against the Effect of Service Quality on Customer Satisfaction 
Information:

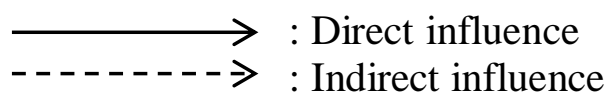

Significance Test Results of the Effect of Service Quality Variable Mediation on the Effect of Customer Satisfaction on Customer Loyalty

To find out whether there is an influence of mediation on the effect of independent variables on the dependent variable, the Sobel Test formula is used:

$$
\mathrm{Z}=\frac{a \times b}{\sqrt{(\boldsymbol{a} 2 \times \text { Seb2 })+(b 2 \times \text { Sea2 })}}
$$

Before the calculation of the significance of the mediation effect, two regressions need to be done, namely the regression of the independent variable $(X)$ on the mediating variable $(Z)$ to produce a coefficient $\alpha$ and the mediation variable regression $(Z)$ to the dependent variable $(Z)$ to produce a coefficient $b$. Based on the sub-structure I equation, the $\alpha$ coefficient is 0.238 with a standard error (Sea) of 0.971 . The coefficient $b$ is 0.256 with a standard error (Seb) of 0.073 presented in the following table:

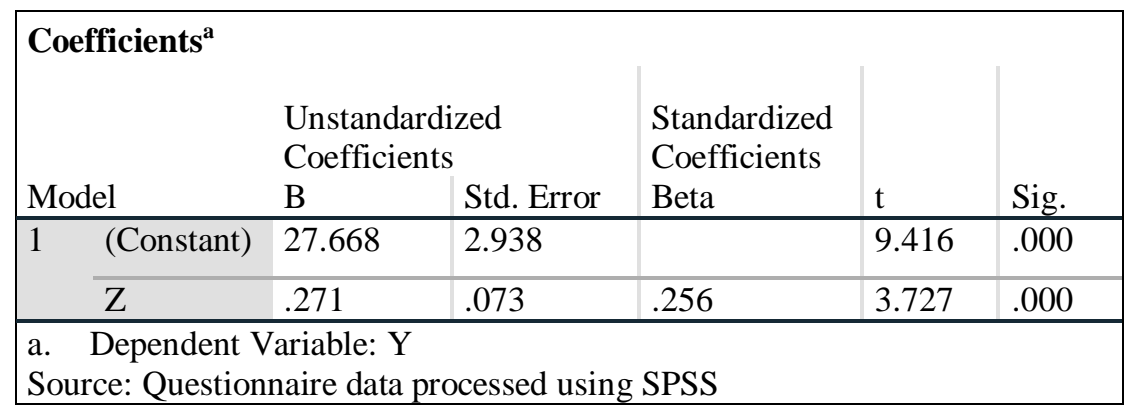

So the results of the mediation significance test are:

$$
\begin{aligned}
& Z=\frac{0,238 \times 0,256}{(0,238 \times 0,073) 2+(0,256 \times 0,971) 2} \\
& Z=0,985
\end{aligned}
$$

Zvalue obtained is 0.985 greater than the Ztable value of 0.82 , because the value of Zvalue is smaller than the value of Ztable 0.82, the decision taken for the mediating effect of $\mathrm{H} 4$ is the variable customer satisfaction mediates the effect of service quality on customer loyalty.

\section{DISCUSSION}

\section{Effect of Service Quality on Customer Satisfaction}

From the results of statistical data analysis for testing the first hypothesis (H1) that has been done in the calculation of the path analysis of sub-structural equations I, shows the beta coefficient value of 0.238 . then the $t$-count test results show a value of $p$ (sig.) of 0.001 smaller than $0.05(0.001>0.05)$. So that the decision taken for H1 is Service Quality has a significant effect on Customer Satisfaction. Service Quality is one of the drivers of consumer satisfaction. The quality of service is also one of the keys to success for the Palembang Horison Ultima Hotel. Business owners must provide good and maximum services in accordance with consumer expectations in order to build customer satisfaction, so that service providers have a good 


\section{International Journal of Business Management and Economic Review}

Vol. 2, No. 04; 2019

ISSN: 2581-4664

relationship with consumers.

\section{Effect of Service Quality on Customer Loyalty}

From the results of testing the second hypothesis $(\mathrm{H} 2)$ that has been done on the calculation of Path Analysis (Path analysis) Sub-structural Equations II, shows the beta coefficient value of 0.343. Furthermore, the results of the t-test show that the value of $p$ (sig.) Of 0,000 is smaller than $0.05(0,000<0,05)$. So the decision taken for $\mathrm{H} 3$ is to accept $\mathrm{Ha}$, so service quality has a significant effect on customer loyalty. The second hypothesis (H2) service quality has a significant effect on customer loyalty. Quality of service is the most important part of a company to meet consumer expectations and make consumers loyal to the company. So the company will continue to maintain consumer loyalty by improving the quality of service from the Horison Ultima Hotel service company Palembang.

\section{Effect of Customer Satisfaction on Customer Loyalty}

Variable Customer satisaction is measured through the Repeat Purchase (loyalty to product purchases), Retention (Resistance to negative influences about the company), and Referrals (referring in total the existence of the company). From the results of testing the second hypothesis (H3) that has been done on the calculation of Path Analysis (Path analysis) Substructural Equations II, shows the beta coefficient value of 0.174. Furthermore, the results of the t-test show that the value of p (Sig.) Of 0.009 is smaller than $0.05(0.009<0.05)$. So that the decision taken for $\mathrm{H} 2$ is to accept $\mathrm{Ha}$, so customer satisfaction has a significant effect on customer loyalty. The second hypothesis (H3) service quality has a significant effect on customer loyalty, satisfie

d consumers will have a high level of loyalty to a service compared to dissatisfied consumers. Consumer satisfaction is one of the factors that can influence consumer loyalty, satisfied consumers will have a high level of loyalty to the company Horison Ultima Hotel Palembang.

4. Significance test results of the service quality variable mediation effect on Customer Satisfaction on Customer Loyalty

Path analysis using the Sobel test was used to prove the 4th hypothesis and to determine the effect of service quality on Customer loyalty mediated by Customer satisfaction Hotel Horison Ultima. Mediation testing using Sobel test. The purpose of this test was to determine the mediating effect of Customer satisfaction at the Horison Ultima Hotel Palembang. From the results of calculations, the Zvalue calculation of 0.985 is greater than the Ztable value of 0.82 , because the value of Zvalue is greater than Ztabel. The variable customer satisfaction is proven to mediate, then the decision taken for the mediating effect of hypothesis $4(\mathrm{H} 4)$ is the variable Costumer satisfaction to mediate the effect of service quality on customer loyalty.

\section{CONCLUSION}

The purpose of this study was to determine the Effect of Service Quality on Consumer Loyalty with Consumer Satisfaction as a Mediation Variable, as well as to determine the direct and indirect effects of research variables. Based on the results of the research and discussion it can be concluded:

1. Service quality is proven to significantly affect customer satisfaction.

2. Customer satisfaction is proven to significantly affect customer loyalty. 


\section{International Journal of Business Management and Economic Review}

Vol. 2, No. 04; 2019

ISSN: 2581-4664

3. Service quality is proven to significantly affect customer loyalty.

4. Customer satisfaction is proven to mediate the effect of service quality on customer loyalty at the Palembang Horison Ultima Hotel.

\section{REFERENCE}

Abdul K., Muhammad B., Rodi. 2018. Pengaruh Kualitas Pelayanan Terhadap Kepuasan, Nilai, Kepercayaan dan Loyalitas Pelanggan Rumah Tangga Pada Perusahaan Daerah Air Minum Kota Kendari. Journal Publiuho. ISSN:2460-058.

Adhitya R., Suryono. 2018. Analisis Pengaruh Kualitas Informasi, Kualitas Sistem dan Kualitas Pelayanan Terhadap Minat Beli Ulang Dengan Kepuasan Pelanggan Sebagai Variabel Intervening (Studi pada Pelanggan Traveloka di Kota Semarang). Diponegoro Journal of Management. Volume 7, Nomor 2, Tahun 2018, Halaman 1-14 ISSN (Online): 2337-3792.

Afifa F., N. Rachma, Afi. 2018. Pengaruh Online Marketing dan E-Service Quality Terhadap Loyalitas Dengan Kepuasan Sebagai Variabel Intervening Pada Online Shop Joyism Malang. e - Jurnal Riset Manajemen.

Ahmad M., Andi T. H., Cicik. 2017. "The Effect of Service Quality, Price and Credibility Qualityof Customer Loyalty with Customer Satisfaction as Intervening Variable (Study On Honda Semarang Center). Jurnal Ekonomika dan Bisnis.

Aji N., Rizal. 2018. Pengaruh Kualitas Layanan Terhadap Kepuasan Pelanggan Jasa Pengiriman Lazada Express Saat Harbolnas di E-Commerce.Diponegoro Journal of Management. Volume 7 Nomor 4, Tahun 2018, Halaman 1 - 11. ISSN (Online): 2337-3792.

Ali M., Mukeri, Leonardo. 2018. The Effect of Ralationship Marketing, Quality of Service and Customer Satisfaction to Customer Loyalty inPT. Panelia Ekysatya Demak. Jurnal Ekonomika dan Bisnis.

Anthony H., Fransisca. 2019. Pengaruh Kualitas Produk, Kualitas Layanan, dan Lingkungan Fisik Terhadap Loyalitas Pelanggan Melalui Kepuasan Pelanggan Sebagai Variabel Mediasi di DE Mandailing Cafe Surabaya. Jurnal AGORA. Vol. 7, No. 1 (2019).

Arie S. W., Heny K. S., Lilik. 2018. The Effevts of VPTI'S Corporate Image and Service Quality on Satisfaction and Loyalty of The KSO SCISI Customer. Indonesian Journal of Business and Entrepreneurship. Vol. 4 No. 1, January 2018. Institut Pertanian Bogor.

Arif D. P., Suprihatmi S., Suprayitno. 2018. Pengaruh Kualitas Produk, Kualitas Pelayanan, dan Promosi Terhadap Loyalitas Pelanggan Dengan Kepuasan Pelanggan Sebagai Variabel Moderasi (Studi pada pelanggan Brownies Amanda Surakarta Cabang Nusukan). Jurnal Ekonomi dan Kewirausahaan. Vol. 18 No. 3 September 2018: 462 - 472.

Berlian N., Budi. 2018. Analisis Pengaruh Kualitas Layanan, Nilai Nasabah, dan Customer Relationship Management Terhadap Kepuasan Nasabah Serta Loyalitas Nasabah (Studi Pada Nasabah BNI Syariah Kantor Cabang Semarang dan Kantor Cabang Pembantu UNISULA). Diponegoro Journal of Management. Volume 7, Nomor 4, Tahun 2018, Halaman 1-12. ISSN (Online): 2337-3792.

Brigitte T., Ferdy R., Farlane. 2019. Pengaruh Kualitas Pelayanan, Harga dan Kualitas Produk Terhadap Kepuasan Konsumen Pada Rumah Makan Raja Oci Manado. Jurnal EMBA. Vol.7 No.1 Januari 2019, Hal. 891 - 900. ISSN 2303-1174.

Danang, Sunyoto. 2013. Metodologi Penelitian Akuntansi. Bandung: PT. Refika Aditama 


\section{International Journal of Business Management and Economic Review}

Vol. 2, No. 04; 2019

ISSN: 2581-4664

Anggota Ikapi.

Faradina, Liviesta. 2018. Pengaruh Kualitas Pelayanan Terhadap Loyalitas Pelanggan Pada PT.

Elteha Cargo Pekanbaru. JOM FISIP. Vol. 5: Edisi I Januari - Juni 2018. Universitas Riau.

Fredi, Pradana. 2018. Pengaruh Manajemen Hubungan Pelanggan, Kualitas Pelayanan dan

Kualitas Pengalaman Terhadap Loyalitas Pelanggan Dengan Kepuasan Pelanggan Sebagai

Variabel Intervening Pada Nasabah PT. Fac Sekuritas Indonesia di Yogyakarta. Jurnal

Manajemen Bisnis. Vol 9. No 2, September 2018, E-ISSN:2622-6308 P-ISSN:2086-8200.

Ghozali, Imam. 2013. Aplikasi Multivariate dengan Program SPSS. Edisi Ketujuh. Semarang:

Badan Penerbit Universitas Diponegoro.

Herdiansyah. Haris. 2013. Wawancara Observasi dan Fokus Grups Sebagai Instrumen Penggalian Data Kualitatif. Jakarta: Rajawali Press.

Iffatin M., Ute Ch., Agung. 2018. Analisis Pengaruh Kualitas Pelayanan, Harga, dan Promosi Terhadap Kepuasan Pelanggan (Studi kasus pada CV. Fastprint Indonesia, JL. Manyar Kertoarjo VII no. 36 Surabaya). Jurnal Universitas Negeri Surabaya.

Jeremia K., Djurwati. 2019. Pengaruh Service Quality, Trust, dan Consumer Satisfaction Terhadap Consumer Loyalty Pada CV. Sarana Marine Fiberglass. Jurnal EMBA. Vol.7 No.1 Januari 2019, Hal. 831 - 840. ISSN 2303-1174.

Kotler dan Keller. 2012. Manajemen Pemasaran. Edisi 12. Jakarta: Erlangga.

Kotler, Philip., Amstrong, Gary. 2014. Prinsip-prinsip Manajemen. Edisi 14, Jilid 1. Jakarta: Erlangga.

Mudrajat, Kuncoro. 2013. Manajemen Riset untuk Bisnis dan Ekonomi. Edisi 4. Jakarta: Erlangga.

Moch. Romzi A., N Rachma, Afi. 2015. Pengaruh Nilai Pelanggan dan Kualitas Layanan Terhadap Loyalitas Pelanggan Melalui Kepuasan Pelanggan di Bukalapak (Studi Kasus pada Mahasiswa Manajemen FEB Unisma Angkatan 2015). $e$ - Jurnal Riset Manajemen Prodi Manajemen.

Siti N., Leonardo B. H., Cicik. 2018. Analisis Pengaruh Kualitas Pelayanan, Harga, dan Lokasi

Terhadap Kepuasan Pelanggan (Studi pada Bengkel Garasi di Ungaran). Jurnal Ekonomi dan Bisnis.

Siskawati, Rahman. 2019. Pengaruh Kualitas Pelayanan dan Inovasi Terhadap Kepuasan Pelanggan Pada PT. PLN (Persero) Area Manado. Jurnal EMBA. Vol.7 No.1 Januari 2019, Hal. 301 - 310. ISSN 2303-1174.

Sugiyono. 2012. Metode Penelitian Administrasi, Bandung: CV. Alfabeta.

Tjiptono, Fandy., Gregorius. 2012. Pemasaran Strategik. Yogyakarta: Andi

Tri A., Ayun M., Agung. 2018. Analisis Pengaruh CitaRasa, Kualitas Pelayanan dan Harga Terhadap Kepuasan Pelanggan (Studi Kasus Bakso Gibrass Jl. Kutisari Selatan No. 45 Surabaya). Jurnal Universitas Negeri Surabaya.

Vellan A., Puspita. 2018. Pengaruh E-ServiceQuality Terhadap E-Customer Satisfaction dan ECustomer Loyalty (Studi Kasus Pada Konsumen Pegipegi di Indonesia). e-Proceeding of Management. Vol.5, No.3 Dsember 2018 | Page 3180. ISSN : 2355-9357. 